\title{
Produção de mudas de eucalipto sob dois sistemas de irrigação e a ocorrência da bacteriose foliar (Xanthomonas axonopodis Vauterin)
}

\author{
Production of eucalypt clones under two irrigation systems and the \\ occurrence of foliar bacteriosis (Xanthomonas axonopodis Vauterin)
}

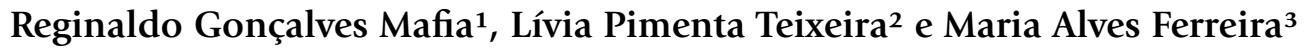

\begin{abstract}
Resumo
No Brasil, a mancha bacteriana e a desfolha causada por Xanthomonas axonopodis Vauterin é uma das doenças mais importantes do eucalipto durante a produção de mudas. O processo infeccioso depende essencialmente da presença de água livre na superfície foliar. Sendo assim, com o presente trabalho objetivou-se avaliar a efetividade do controle da doença por meio de uma tecnologia alternativa de irrigação, com eliminação da presença de água livre sobre as folhas. Os resultados permitiram concluir que o uso da subirrigação reduziu a intensidade da doença, aumentou o desenvolvimento e o aproveitamento das mudas, em comparação ao sistema de irrigação por aspersão. O uso da tecnologia de subirrigação é mais uma alternativa de manejo integrado da doença nos viveiros de eucalipto.
\end{abstract}

Palavras-chave: Controle de doença, viveiro, produção de mudas.

\begin{abstract}
In Brazil, bacterial spot and defoliation caused by Xanthomonas axonopodis Vauterin is one of the most important disease of eucalyptus during the seedlings production. The infectious process depends essentially on the presence of free water on the leaf surface. Therefore, this study aimed to evaluate the effectiveness of disease control through an alternative technology of irrigation, with elimination of the presence of free water on the leaves. The results showed that the use of sub-irrigation reduced the intensity of the disease, increased development and use of seedlings compared to sprinkler irrigation system. The use of subirrigation technology is another alternative to integrated management of disease in eucalyptus nurseries.
\end{abstract}

Keywords: Disease control, nursery, clone production.

\section{INTRODUÇÃO}

Xanthomonas axonopodis Vauterin causa a mancha bacteriana e desfolha do eucalipto, sendo considerado um dos patógenos mais importantes do eucalipto durante a fase de produção de mudas. No Brasil, a doença está amplamente distribuída e tem causado perdas expressivas em viveiros, especialmente em regiões e épocas do ano mais quentes, sobretudo quando associada com maior intensidade e frequência de chuvas.

Os sintomas da doença podem variar, dependendo da espécie de eucalipto, fase do processo produtivo das mudas, estágio fenológico das folhas e grau de desenvolvimento da lesão (GONÇALVES et al., 2008). Todavia, inicialmente e de forma geral os sintomas dessa doença caracterizam-se por lesões encharcadas do tipo anasarca, internervurais, angulares, concentradas ao longo da nervura principal, nas margens da folha e, quando em maiores intensidades, distribuídas aleatoriamente sobre o limbo foliar. A incidência severa de bacteriose causa desfolha das mudas durante a fase de viveiro. As folhas totalmente expandidas são mais suscetíveis à bacteriose foliar (NEVES, 2007).

O controle da bacteriose foliar pode ser realizado de forma eficiente pela seleção e plantio de clones de eucalipto resistentes. Existe variabilidade entre e dentro das espécies de eucalipto para resistência a bacteriose foliar, conforme observado também para outras doenças causadas por bactérias (ARRIEL et al., 2014; FERRAZ et al., 2015; MAFIA et al., 2014). Todavia, a seleção de clones resistentes,

${ }^{1}$ Coordenador de pesquisa. Fibria Celulose S.A. / Centro de Tecnologia. Rod. Aracruz - Barra do Riacho, Km 25- Caixa Postal 331011 - 29197-900 - Aracruz, ES, Brasil. E-mail: rgoncalves@ fibria.com.br.

${ }^{2}$ Doutora em Agronomia. UFLA - Universidade Federal de Lavras. Caixa Postal 3037 - 37200-000, Lavras, MG, Brasil. E-mail: liupimenta@yahoo.com.br.

3Professor Titular no Departamento de Fitopatologia. UFLA - Universidade Federal de Lavras. Caixa Postal 3037 - 37200 000, Lavras, MG , Brasil. E-mail: ferreirama.ufla@gmail.com.

Sci. For., Piracicaba, v. 45, n. 116, p. 697-704, dez. 2017 DOI: dx.doi.org/10.18671/scifor.v45n116.10 
Mafia et al. - Produção de mudas de eucalipto sob dois sistemas de irrigação

e a ocorrência da bacteriose foliar (Xanthomonas axonopodis Vauterin)

especificamente, para bacteriose foliar não tem sido priorizada, em função das dificuldades de agregar em um único indivíduo várias características silviculturais e tecnológicas da madeira, além da resistência a outras doenças de maior dificuldade de controle pelo manejo florestal (ASSIS; MAFIA, 2007).

Para as doenças causadas por bactérias, o processo infeccioso depende, essencialmente, da presença de água livre na superfície foliar. Sendo assim, em viveiros para produção de mudas de eucalipto, em função da adoção do sistema de irrigação por aspersão em praticamente todas as fases do processo produtivo, prevalecem condições favoráveis à doença. O presente trabalho objetivou avaliar a relação entre a quantidade de água aplicada pelos sistemas de irrigação no estabelecimento e desenvolvimento em viveiro da mancha bacteriana e desfolha do eucalipto, causada por $X$. axonopodis.

\section{MATERIAL E MÉTODOS}

Os experimentos foram conduzidos em um viveiro clonal no qual todas as fases do processo de produção de mudas de eucalipto são realizadas em estruturas cobertas com teto plástico. O primeiro experimento foi realizado com mudas de três clones híbridos de eucalipto E. urophylla x E. globulus (CL01, CL02 e CL03) com diferentes níveis de suscetibilidade à doença. No segundo experimento, o clone mais suscetível foi utilizado para comprovação dos resultados obtidos anteriormente, em uma larga escala de produção de mudas.

\section{Produção das mudas}

As mudas dos três clones de eucalipto foram produzidas pela técnica de miniestaquia. Para isso, miniestacas foram coletadas de matrizes e submetidas ao enraizamento em substrato composto de casca de arroz carbonizada e vermiculita $(1: 1 \mathrm{v} / \mathrm{v})$, em recipientes do tipo tubete plástico (50 $\mathrm{cm}^{3}$ de capacidade). Após 30 dias na fase de enraizamento, em casa de vegetação com teto plástico e irrigação por nebulização, as mudas obtidas foram transferidas para estruturas de aclimatação e crescimento também protegidas com cobertura plástica. A fertilização das mudas foi realizada mediante a aplicação de uma solução nutritiva contendo macro e micronutrientes essenciais ao desenvolvimento (ALFENAS et al., 2009).

\section{Efeito da tecnologia de irrigação sobre a intensidade da doença}

A intensidade da bacteriose foliar, em condições naturais de infecção do patógeno, foi comparada considerando o processo de produção de mudas com adoção do sistema de irrigação por aspersão em relação ao sistema de subirrigação, onde não há molhamento foliar. Para isso, as mudas produzidas conforme descrito anteriormente foram mantidas até 90 dias de idade nos dois sistemas de irrigação. A irrigação por aspersão foi realizada com emissores de vazão 360 l/h, aplicando-se uma lâmina de 5,5 a 8,5 mm/dia, dependendo da condição do clima. No sistema de subirrigação as mudas foram mantidas em bandejas de aço inox suspensas, com os tubetes parcialmente imersos em água na mesma frequência de irrigação adotada no sistema de aspersão.

\section{Delineamento experimental e análise estatística}

O primeiro experimento foi instalado em um delineamento inteiramente casualizado em esquema fatorial, composto ( 3 clones de eucalipto x 2 sistemas de irrigação) de dez repetições. Cada unidade amostral foi composta por uma bandeja contendo 75 mudas. As avaliações foram realizadas após as mudas completarem 90 dias de idade. A intensidade da doença foi quantificada pela incidência e severidade da doença. A incidência foi determinada considerando o percentual de plantas doentes em relação ao total de mudas em cada unidade amostral. Para determinar a severidade da doença, as mudas doentes foram avaliadas com auxílio de uma escala de notas (Tabela 1). Além da intensidade da doença, o crescimento foi avaliado quantificando-se a altura das mudas, o número de folhas, a biomassa seca de raízes e da parte aérea.

O segundo experimento foi instalado em delineamento inteiramente casualizado, no qual os dois sistemas de irrigação foram comparados, considerando a produção de mudas ao longo de um ano. Cada unidade amostral foi composta dos lotes produzidos por semana, totalizando 1,5 milhão de mudas produzidas e avaliadas em cada tratamento. As mudas foram avaliadas quanto 
à intensidade da doença, conforme descrito anteriormente. O aproveitamento final de mudas foi quantificado para as duas tecnologias de irrigação. As mudas severamente atacadas pela doença (notas 4 e 5) foram descartadas, enquanto as demais (notas de 0 até 3 ) foram consideradas adequadas para plantio. O aproveitamento final de mudas foi determinado pela relação percentual entre as mudas adequadas para plantio em relação ao total de mudas produzidas.

Tabela 1. Escala de notas para avaliação da severidade da bacteriose foliar, causada por Xanthomonas axonopodis, em eucalipto.

Table 1. Grading scale of notes for evaluating the severity of leaf blight, caused by Xanthomonas axonopodis, in eucalypts.

\begin{tabular}{lcll}
\hline Nota & Desfolha & Lesões foliares & Necrose e lesões nos pecíolos \\
\hline 0 & Ausente & Ausente & Ausente \\
1 & Ausente & Poucas e menores que $5 \mathrm{~mm}$ de diâmetro & Ausente \\
2 & Ausente & Início da coalescência das lesões foliares & Início \\
3 & Início & Presente somente nas folhas mais velhas & Presente \\
4 & Presente & Nas folhas mais velhas e em folhas novas & Intensa \\
5 & Intensa & Todas as folhas intensamente afetadas & Intensa \\
\hline
\end{tabular}

As análises estatísticas foram realizadas com auxílio do software Statistica v.10 (STATSOFT, 2011). Os dados, após confirmação das pressuposições necessárias, foram submetidos à análise de variância e as médias comparadas pelo teste Tukey $(\mathrm{P}<0,05)$.

\section{RESULTADOS E DISCUSSÃO}

De forma geral, considerando os clones testados e as variáveis analisadas, a intensidade da doença foi menor para a tecnologia de subirrigação quando comparado com a irrigação por aspersão. Além disso, o clone CL02 foi mais suscetível à mancha e desfolha bacteriana (Figuras 1A e 1B).

A incidência da doença variou de 6 a 78\%, dependendo do tratamento. Houve efeito da interação entre clone de eucalipto e tipo de irrigação. Houve maior incidência da doença para o clone CL02, com média igual a 45\% considerando os dois sistemas testados. Os clones CL01 e CL03 não diferiram entre si e apresentaram 36 e 30\% de incidência da doença, respectivamente. Para todos os três clones houve menor incidência da doença quando as mudas foram produzidas utilizando-se o sistema de subrrigação. O uso da tecnologia de subirrigação permitiu reduzir em 11, 6 e 8 vezes a incidência da doença para os clones CL01, CL02 e CL03, respectivamente (Figura 1A).

A severidade da doença variou de acordo com o clone de eucalipto e a tecnologia de irrigação, entre 0,22 a 3,82. Considerando o efeito da interação entre estes fatores, a severidade máxima foi observada para o clone CL02 no sistema de irrigação por aspersão. A menor severidade foi observada no sistema de subirrigação para os três clones, sendo igual a 0,22 para os clones CL01 e CL03 e 0,58 para o clone CL02. A severidade da doença foi 6 a 9 vezes menor no sistema de subirrigação quando comparada ao sistema de aspersão, dependendo do clone considerado (Figura 1B). No Brasil, os viveiros são construídos com estruturas de aclimatação, crescimento e rustificação a céu aberto, muitas das vezes, em função das condições favoráveis de clima e para redução do investimento inicial. Todavia, a ocorrência de períodos prolongados de chuva pode causar o aumento da incidência de doenças, principalmente bacteriose foliar, pela presença constante de água livre sobre as folhas. Além da ocorrência de chuvas e pelos resulados do presente trabalho foi possível comprovar que a água de irrigação também é um fator epidemiológico importante que pode favorecer bacteriose foliar do eucalipto. Verificou-se que a intensidade da doença foi maior quando as mudas de eucalipto foram produzidas em sistema de irrigação por aspersão, que notadamente aumenta o tempo de molhamento foliar, em relação à tecnologia de subirrigação. A irrigação por aspersão permite a formação de uma lâmina de água constante sobre a folha, o que favorece o início da infecção e o progresso da doença. Para estabelecer a infecção em condições naturais, $X$. axonopodis requer água livre na superfície da folha e nos espaços intercelulares. O condicionamento prévio de plantas em alta umidade do ar e a manutenção das plantas nesta condição favorecem o estabelecimento da doença (NEVES, 2007). Além de favorecer o estabelecimento da doença, a água de irrigação pode influenciar na disseminação do patógeno, por meio dos respingos de gotas contendo células bacterianas (GONÇALVES et al., 2008), sendo um dos fatores de maior risco para disseminação de 
Mafia et al. - Produção de mudas de eucalipto sob dois sistemas de irrigação

e a ocorrência da bacteriose foliar (Xanthomonas axonopodis Vauterin)

inóculo de patógenos em viveiros clonais de eucalipto (MAFIA et al., 2008). Dessa maneira, tecnologias têm sido avaliadas para tratamento da água visando seu reaproveitamento e evitar a disseminação de patógenos em viveiros de eucalipto (MACHADO et al., 2013).

A importância da água de irrigação na epidemiologia de doenças é um fator conhecido e amplamente estudado (LAMICHHANE; BARTOLI, 2015). O uso da subirrigação e irrigação por gotejamento já foi confirmado como estratégia para o controle de manchas bacterianas em outras culturas, principalmente hortaliças (KRAUTHAUSEN et al, 2011). Por exemplo, em pêssego a mancha foliar causada por $X$. campestris pv. pruni ocorreu em períodos mais longos de molhamento foliar (ZEHR et al., 1996). Em citrus, a incidência da mancha-foliar, causada por X. smithii ssp. citri, foi observada após um período extenso de molhamento, sendo a maior incidência, observada após 24 horas de irrigação (PRIA et al., 2006).
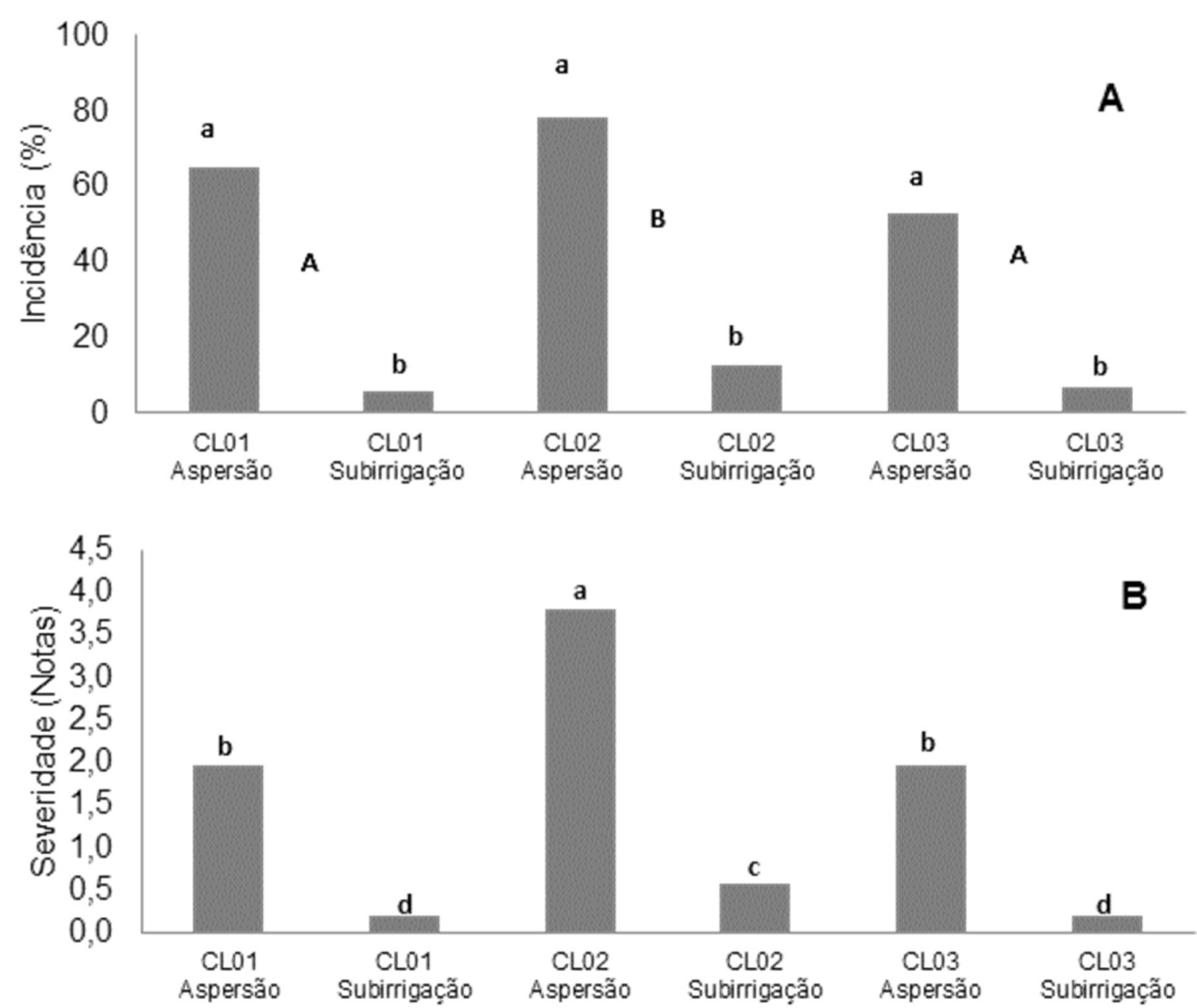

Figura 1. Intensidade da bacteriose foliar em função da tecnologia de irrigação, material genético e interação entre estes fatores. A- Incidência (\%) da doença. As letras minúsculas são comparações das médias entre os sistemas de irrigação. As letras maiúsculas são comparações entre os clones de eucalipto independentemente da tecnologia de irrigação. B- Severidade (\%) da bacteriose foliar. As letras minúsculas são comparações entre todos os tratamentos. As médias foram comparadas pelo teste de Tukey $(p<0,05)$.

Figure 1. Intensity of leaf blight due to: the irrigation technology used; clones; and interaction between these factors. A- Incidence (\%) of disease. Lowercase letters are averages of comparisons between irrigation systems. The capital letters are comparisons between eucalyptus clones regardless of irrigation technology. B- Severity (\%) of leaf blight. Lowercase letters are comparisons between all the treatments. Means were compared by Tukey test $(p<0.05)$.

O crescimento em altura das mudas variou de acordo com o material genético e com o tratamento de irrigação, mas não houve efeito da interação entre estes fatores. As mudas, dos três clones, produzidas no regime de subirrigação apresentaram maior crescimento em altura. Além disso, os clones CL01 e CL03 apresentaram maiores valores médios para esta variável. Para estes clones a altura foi aproximadamente $34 \%$ maior quando produzidas em sistema de subrrigação em relação à aspersão. Para o clone CL02 o ganho foi de 43\% quando estes tratamentos foram comparados 
(Figura 2A). O manejo inadequado da irrigação, bem como a ocorrência de chuvas, pode provocar a lixiviação de nutrientes. Como consequência, pode ocorrer a debilitação das plantas e o favorecimento da ocorrência de determinados patógenos. O número de folhas variou de acordo com a interação entre clone e métodos de irrigação. Considerando a interação entre estes fatores, o maior número de folhas foi verificado nos tratamentos com subirrigação para o clone CL02, seguido dos clones CL01 e CL03, que não diferiram entre si. As mudas do clone CL02 no sistema de subirrigação apresentaram em média 2,7 vezes mais folhas do que as mudas do mesmo clone no sistema de aspersão (Figura 2B).
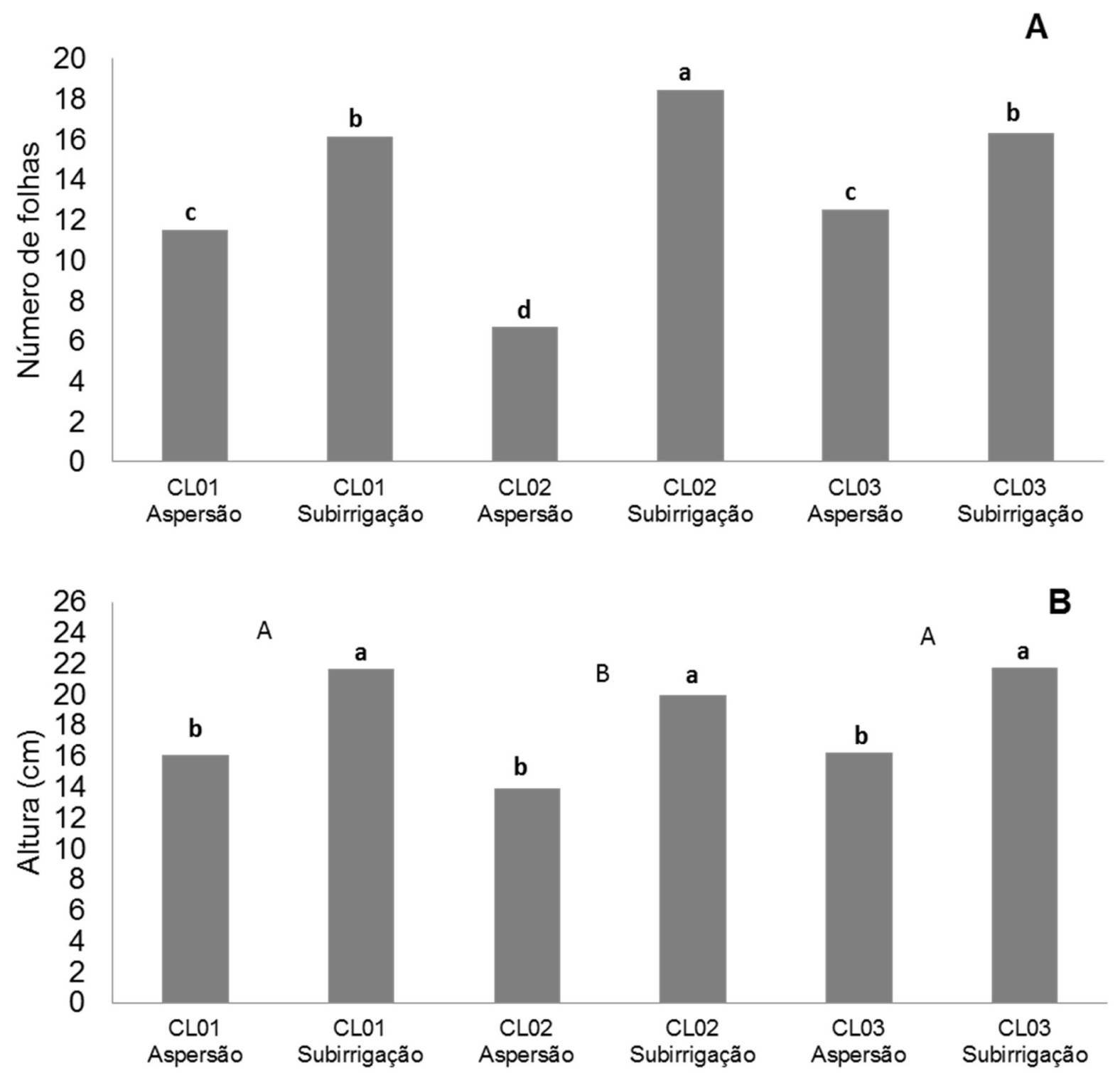

Figura 2. Crescimento das mudas de eucalipto em função da tecnologia de irrigação, material genético e interação entre estes fatores. A- Altura $(\mathrm{cm})$ das mudas. As letras minúsculas são comparações das médias entre os sistemas de irrigação. As letras maiúsculas são comparações entre os clones de eucalipto independentemente da tecnologia de irrigação. B- Número de folhas (n). As letras minúsculas são comparações entre todos os tratamentos. As médias foram comparadas pelo teste de Tukey $(p<0,05)$.

Figure 2. Growth of eucalyptus cuttings according to: irrigation technology, clones, and interaction between these factors. A- Height $(\mathrm{cm})$ of seedlings. Lowercase letters are averages of comparisons between irrigation systems. The capital letters are comparisons between eucalyptus clones regardless of irrigation technology. B- Number of leaves $(n)$. Lowercase letters are comparisons between all the treatments. Means were compared by Tukey test $(p<0.05)$.

O desenvolvimento das raízes não foi afetado pelos métodos de irrigação e pelos clones testados (Figura 3A). Por outro lado, a biomassa da parte aérea variou de acordo com o método de irrigação, independentemente do clone testado. De forma geral as mudas produzidas no sistema de subirrigação apresentaram maior biomassa da parte aérea em relação à irrigação por aspersão. A 
Mafia et al. - Produção de mudas de eucalipto sob dois sistemas de irrigação

e a ocorrência da bacteriose foliar (Xanthomonas axonopodis Vauterin)

diferença entre os tratamentos foi de 85 e 87\% para os clones CL01 e CL03, respectivamente. Para o clone CL02 as mudas produzidas em sistema de subirrigação apresentaram $116 \%$ de ganho para biomassa da parte aérea, quando produzidas no mesmo sistema de irrigação (Figura 3B). Embora não tenha sido avaliado no presente trabalho, o sistema de subirrigação apresenta um menor risco para lixiviação dos nutrientes e permite uma fertilização mais equilibrada das mudas (DUMROESE et al., 2006). Uma evidência disso foi o maior desenvolvimento das mudas produzidas neste tipo de sistema de irrigação. Conforme observado, a biomassa da parte aérea foi maior em mudas produzidas no sistema de subirrigação.

A biomassa de raízes não foi afetada pelos tratamentos, muito provavelmente pela limitação do espaço disponível para o sistema radicular nos tubetes de produção das mudas. Em um estudo, sobre a influência da fertilização sobre a bacteriose foliar do eucalipto (SILVA, 2007), foi observado que a intensidade da doença reduziu com o aumento dos níveis de potássio na solução nutritiva e que a incidência da bacteriose reduziu com o aumento da concentração de $\mathrm{KCl}$ aplicada.

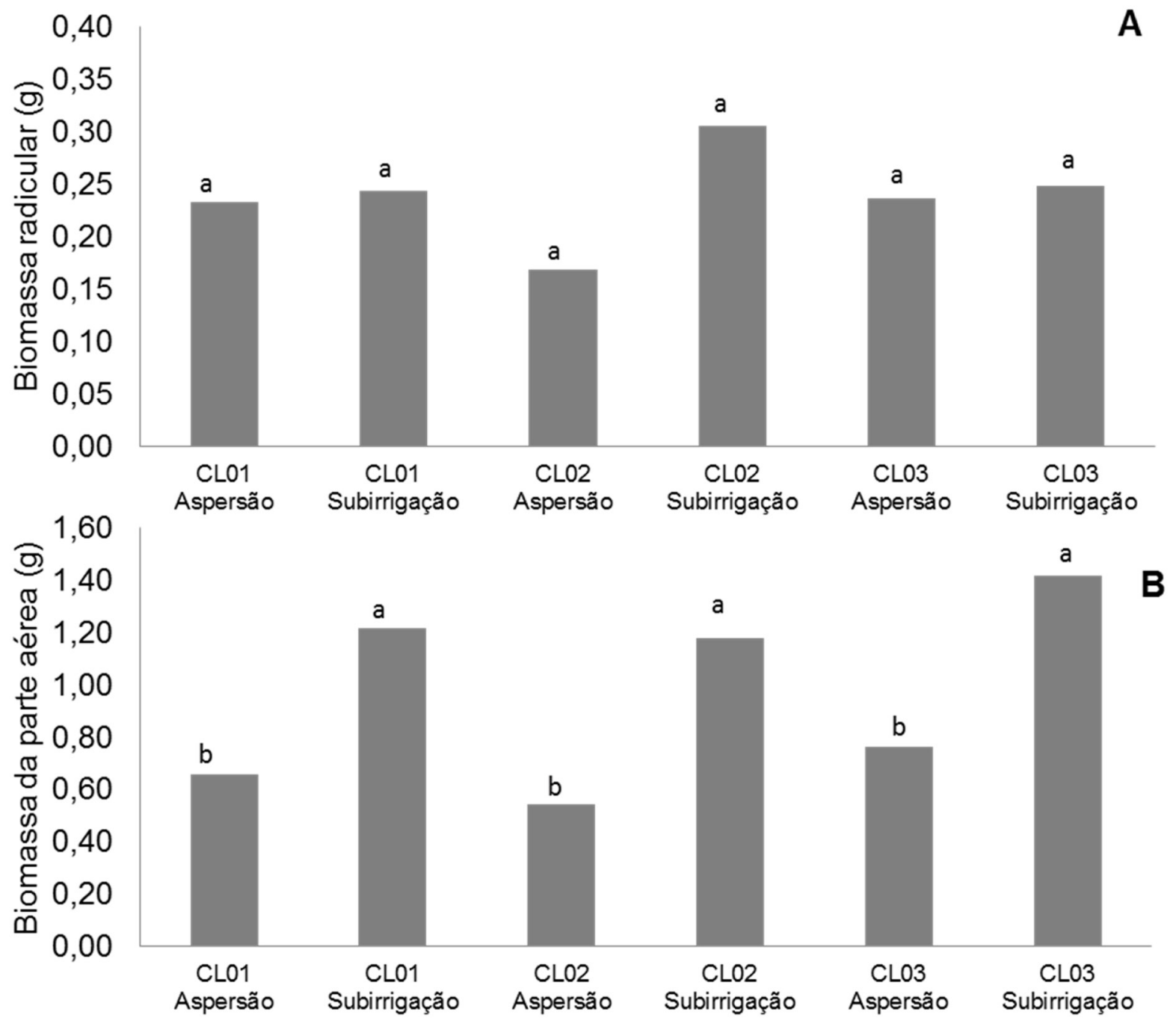

Figura 3. Crescimento das mudas de eucalipto em função da tecnologia de irrigação, material genético e interação entre estes fatores. A- Biomassa radicular $(\mathrm{g})$. As letras minúsculas são comparações das médias entre os sistemas de irrigação e clones de eucalipto. B- Biomassa da parte aérea $(\mathrm{g})$. As letras minúsculas são comparações entre os sistemas de irrigação para cada clone testado. As médias foram comparadas pelo teste de Tukey $(p<0,05)$.

Figure 3. Growth of eucalyptus cuttings according to: irrigation technology, clones, and interaction between these factors. A- Root biomass $(\mathrm{g})$. Lowercase letters are comparisons of means between irrigation systems and eucalyptus clones. B- Plant biomass $(\mathrm{g})$. Lowercase letters are comparisons between irrigation systems for each tested clone. Means were compared by Tukey test $(p<0.05)$.

O aproveitamento final de mudas, considerando a intensidade de doença variou de acordo com a tecnologia de irrigação. No sistema de aspersão o aproveitamento médio de mudas foi de $6 \%$, enquanto no sistema de subirrigação $92 \%$ das mudas apresentaram baixa intensidade da doença 
e foram classificadas como adequadas para plantio (Figura 4). A tecnologia de irrigação afetou a intensidade da doença. De forma geral, a irrigação por aspersão resultou em aumento da incidência e severidade da bacteriose, em todos os clones testados. A patógena causa perda de tecido foliar de forma direta, ao causar machas no limbo foliar. De forma indireta, a partir de determinada intensidade da doença, ocorre também desfolha prematura das mudas. Este último efeito da doença é, muito provavelmente, o que causa mais drasticamente a redução do crescimento e perda da qualidade das mudas. Conforme observado no presente estudo, em função da intensidade da doença e, principalmente da desfolha, observou-se que o aproveitamento final foi menor quando as mudas foram produzidas no sistema de irrigação por aspersão.

Entre os materiais genéticos testados e de forma geral, o clone CL02 demonstrou maior intensidade da doença. Apesar da variabilidade genética para esta doença, a seleção de clones resistentes não tem sido uma estratégia adotada na prática (ASSIS; MAFIA, 2007). De qualquer forma, conhecendo-se os clones mais suscetíveis para esta doença, torna-se uma opção de manejo realizar a sua propagação em época menos favoráveis para a doença e, preferencialmente, no sistema de subirrigação. Além destas medidas preventivas, existem outras opções que complementam o manejo integrado desta doença em viveiros de eucalipto.

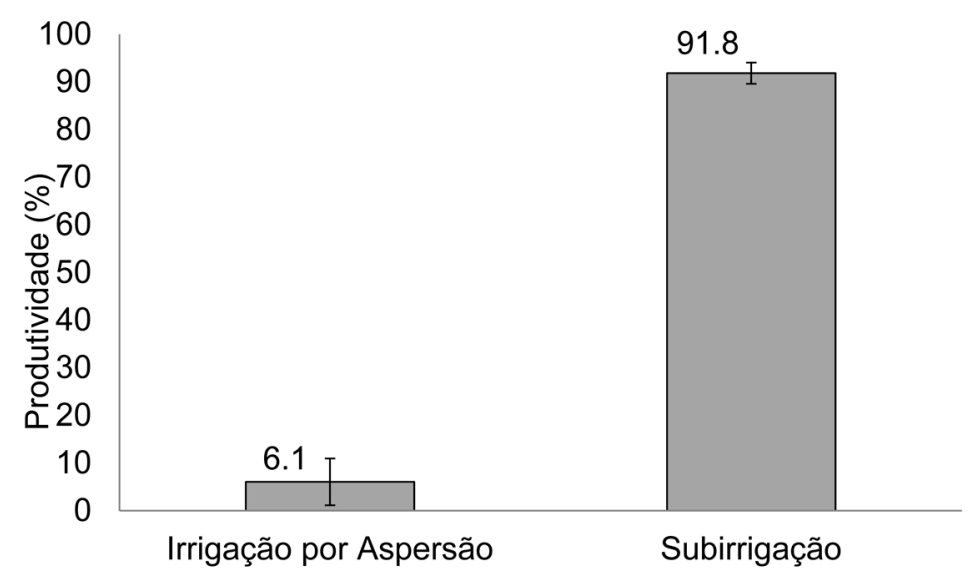

Figura 4. Produtividade (\%) considerando o aproveitamento das mudas de eucalipto sadias de acordo com a tecnologia de irrigação. As barras verticais representam o erro padrão da média.

Figure 4. Productivity $(\%)$ of healthy eucalyptus cuttings in different irrigation technologies. Vertical bars represent the mean standard error.

\section{CONCLUSÕES}

- A tecnologia de subirrigação reduziu a incidência e severidade da bacteriose foliar, em comparação ao sistema de irrigação por aspersão.

- Considerando as plantas com maior incidência e severidade, constatou que o sistema de irrigação de subirrigação influenciou positivamente no tamanho e número de folhas. O mesmo foi observado quando se avaliou biomassa dos tratamentos.

- Constatou-se que o uso de subirrigação proporcionou uma produtividade de mudas em condições de alta pressão da doença.

\section{REFERÊNCIAS BIBLIOGRÁFICAS}

ALFENAS, A. C., ZAUZA, E. A. V., MAFIA, R. G., ASSIS, T. F. Clonagem e doenças do eucalipto. 2 ed. Viçosa: Universidade Federal de Viçosa, 2009. 500 p.

ARRIEL, D. A. A., FONSECA, N. R., GUIMARÃES, L. M. S., HERMENEGILDO, P.S., MAFIA, R.G., BORGES, N., SOUZA, H.P., ALFENAS, A.C. Wilt and die-back of Eucalyptus spp. caused by Erwinia psidii in Brazil. Forest Pathology, v. 44, n. 4, p. 255-265, 2014.

ASSIS, T. F., MAFIA, R. G. Hibridação e clonagem. In: BORÉM, A. (Ed.). Biotecnologia florestal. Viçosa: Suprema, 2007. p. 93-121. 
Mafia et al. - Produção de mudas de eucalipto sob dois sistemas de irrigação

e a ocorrência da bacteriose foliar (Xanthomonas axonopodis Vauterin)

FERRAZ, H. G. M.; DEMUNER, G. A.; GUIMARÃES, L. M. S.; ARRIEL, D. A. A.; SILVA, A. C.; JUNIOR, N. B.; MAFIA, R. G.; ALFENAS, A. C. Methods of inoculation and evaluation of Erwinia psidii in eucalypt. Forest Pathology, v. 46, n. 3, p. 240-247, 2015

DUMROESE, K. R.; PINTO, J. R.; JACOBS, D. F.; DAVIS, A. Horiuchi, B. Subirrigation reduces water use, nitrogen loss, and moss growth in a container nursery. Native Plants Journal, Madson, v. 7, n. 3, p. 253-261, 2006.

GONÇALVES, R. C.; LAU, D.; OLIVEIRA, J. R.; MAFFIA, L. A.; CASCARDO, J. C. M.; ALFENAS, A. C. Etiology of bacterial leaf blight of eucalyptus in Brazil. Tropical Plant Pathology, Brasília, v. 33, n. 3, p. 180-188, 2008.

KRAUTHAUSEN, H. J; LAUN, N.; WOHANKA, W. Methods to reduce the spread of the black rot pathogen, Xanthomonas campestris pv. campestris, in brassica transplants. Journal of Plant Diseases and Protection, v.118, n. 1, p. 7-16, 2011.

LAMICHHANE, J. R.; BARTOLI, C. Plant pathogenic bacteria in open irrigation systems: what risk for crop health? Plant Pathology, v. 64, n. 4, p. 757-766, 2015.

MACHADO, P. S.; ALFENAS, A. C.; COUTINHO, M. M.; SILVA, C. M.; MOUNTEER, A. H.; MAFFIA, L. A.; FREITAS, R. G.; FREITAS, C. S. Erradication of plant pathogens in forest nursery irrigation water. Plant Disease, v. 97, n. 6, p. $80-788,2013$.

MAFIA, R. G., ALFENAS, A. C., FERREIRA, M. A. Avaliação da resistência do eucalipto à murcha-bacteriana causada por Ralstonia solanacearum. Revista Árvore, Viçosa, v. 38, n. 4, p. 649-656. 2014.

MAFIA, R.G., ALFENAS, A.C., FERREIRA, E.M., MACHADO, P.S., BINOTI, D.H.B., LEITE, F.P., SOUZA, F.L. Reuse of untreated irrigation water as a vehicle of inoculum of pathogens in eucalyptus clonal nursery. Tropical Plant Pathology, Brasília, v.33, n.2, p. 96-102, 2008.

NEVES, D.A. Condições favoráveis à mancha foliar causada por Xanthomonas axonopodis em eucalipto. 2007, 22 p. Dissertação (Mestrado em Fitopatologia) - Universidade Federal de Viçosa, Viçosa, 2007.

PRIA, M. D.; CHRISTIANO, R. C. S.; FURTADO, E. L.; AMORIM, L.; BERGAMIN FILHO, A. Effects of temperature and leaf wetness duration on infection of sweet oranges by Asiatic citrus canker. Plant Pathology, v. 55, n. 5, p. 657-663. 2006.

SILVA, A. G. Histopatologia e influência de nutrientes na intensidade da bacteriose foliar do eucalipto causada por Xanthomonas axonopodis. 2007, 71 p. Tese (Doutorado em Fitopatologia) - Universidade Federal de Viçosa, Viçosa, 2007.

STATSOFT, Inc. STATISTICA (data analysis software system), version 10. 2011. Disponível em: < www. statsoft.com >. Acesso em: 10 abr. 2016

ZEHR E., SHEPARD D.P., BRIDGES W.C. Bacterial spot of peach as influenced by water congestion, leaf, wetness duration, and temperature. Plant Disease, v. 80, n. 3, p. 339-341,1996.

Recebido em 08/04/2016

Aceito para publicação em 07/07/2017 